\title{
RIGHT TO INFORMATION: A STEP TOWARDS GOOD GOVERNANCE IN PAKISTAN
}

\author{
Amir Ahmed Khuhro', Ali Nawaz Soomro ${ }^{2}$ \\ ${ }^{1}$ Prof. Dr. Director Institute of International Relations, Shah Abdul Latif University, Khairpur, \\ Pakistan, amir.khuhro@salu.edu.pk \\ ${ }^{2}$ Teaching Assistant \& Ph.D. Research Scholar, Department of Political Science, Shah Abdul Latif \\ University, Khairpur, Pakistan, alinawaz.soomro@salu.edu.pk
}

\begin{abstract}
With the passage of time majority of the states have changed their political system from other kinds to democratic system, because democracy is the only political system which cares for the public opinion. In democracy, the people have right to vote, through which they elect their choice of representatives directly or indirectly. It is the only system for which the term good governance is being used. The term good governance can be used for the government which protects the rights of the people and provide them equal opportunities, care for public opinion, whose policies are clear and crystal before the common peoples and where no underhand game is being played. That's why it is known as a government which is participatory, accountable and transparent, where all the citizens are equal before the law. With the passage of time the laws are made to make the government more accountable and its policies transparent, for this purpose majority of the states have incorporated the right to information in their constitution. Through this right the people can have access to public related information, which enable the peoples to keep an eye on government, in result the corruption can be decreased and it will create more accountable government. Moreover, it will create hindrances in the way of abuse of power and corruption. Pakistan is a democratic state and there is a separate chapter of fundamental rights in the constitution of Pakistan, in April 2010 through eighteenth amendment article 19-A was incorporated in the 1973 constitution of Pakistan regarding right to information aiming to create more accountable, transparent and participatory system. This research paper is an attempt to analyze that how right to information can be a step towards good governance in Pakistan.
\end{abstract}

Keywords: Right to Information, Good Governance, Transparency, Accountability, Government, Democracy, Pakistan.

\section{DEMOCRACY}

Democracy is the unique political system which enables the common people to govern themselves through their directly or indirectly elected representatives. The most important thing in democratic system is right to vote, which enables them to choose their choice of representatives for a specific tenure. This time period makes their representatives more accountable and responsible because after the completion of their tenure they shall have to go to the citizen for casting their vote in his favour for next tenure. That's way it is said that in democracy the power lies in the hands of the people (Kamran, 2008). 
Furthermore, most of the states have adopted representative form of democracy, in which people elect their representatives and then those elected representatives act on their behalf and vote in their interests. On other hand, there is a pure democracy which James Madison mentioned in "The Federalist in 1787" he defines pure democracy as "a society consisting of a small number of citizens, who assemble and administer the government in person" (Hook, 2011, p. 11).

Nowadays, the world is going towards democratic system, but if we go through history the recent three decades witnessed a great change in political system in which mostly states changed their system from military dictatorship to democratic system. Democracy is not just giving right to vote to the common people but that system must be transparent. "democratic leaders can never be entirely free from a commitment to truth-telling" (Shapiro, 2003, p. 200).

"In 1979, fourteen military regimes held power in sub-Saharan Africa, nine in Latin America, five in the Arab states and North Africa, three in Southeast Asia, two in South Asia, and one in East Asia. Since then, democracy replaced all of the military or "quasi-civilian" regimes in Latin America. In the Middle and Near East, military rule has almost universally transformed into civilian strongman rule. In Asia, Bangladesh, Indonesia, South Korea, Thailand and Pakistan have moved from military domination to democracy or mixed patterns of civilianmilitary authority" (Chambers \& Croissant, 2010, pp. 1-2).

Unfortunately, the Pakistan has remained more than half of its period under military rule directly or indirectly. Siegfried $\mathrm{O}$. Wolf \& Seth Kane in their research divided political history of Pakistan into five different periods, they categorized these periods to show how military remained influential on political decision making process.

\begin{tabular}{|c|c|c|}
\hline Structure of Leadership* & Duration & Period \\
\hline Direct Military Rule & 17 years & $\begin{array}{l}\text { 1958-1962: Ayub Khan } \\
\text { 1962-1971: Yahya Khan } \\
\text { 1977-1985: Zia-ul-Haq } \\
\text { 1999-2002: Pervez Musharraf }\end{array}$ \\
\hline $\begin{array}{l}\text { Elected government under } \\
\text { a military president** }\end{array}$ & 15 Years & $\begin{array}{l}\text { 1962-1969: Ayub Khan } \\
\text { 1985-1988: Zia-ul-Haq } \\
\text { 2002-2007: Pervez Musharraf }\end{array}$ \\
\hline $\begin{array}{l}\text { Elected government under } \\
\text { a civilian president } * * *\end{array}$ & $\begin{array}{c}11 \text { years } \\
1988-1999\end{array}$ & $\begin{array}{l}\text { (1) } 1988 \text { - 1990: Benazir Bhutto } \\
\text { (2) } 1990 \text { - 1993: Nawaz Sharif } \\
\text { (3) } 1993 \text { - 1996: Benazir Bhutto } \\
\text { (4) } 1997 \text { - 1999: Nawaz Sharif }\end{array}$ \\
\hline $\begin{array}{l}\text { Semi-Civilian (non-elected) } \\
\text { political government**** }\end{array}$ & $\begin{array}{c}11 \text { years } \\
1947-1958\end{array}$ & $\begin{array}{l}\text { (1) 1947-1951: Liaquat Ali Khan } \\
\text { (2) 1951-1953: Muhammad Ali Bogra } \\
\text { (3) 1953-1955: Chaudry Muhammad Ali } \\
\text { (4) 1956-1957: Husey Shahhed Suhrawardy } \\
\text { (5) 1957-1958: Sir Feroz Khan Noon }\end{array}$ \\
\hline Civil-Military Equilibrium $* * * * *$ & 6 years & 1971-1977: Zulfikar Ali Bhutto \\
\hline \multicolumn{3}{|c|}{$\begin{array}{l}\text { Notes: * The formulated structures of leadership for the various periods represent models to express } \\
\text { the dominant style of governance and political management; Interim-governments and Prime- } \\
\text { Minister under Military President/rule are not taken into account; ** Also referred to as a post } \\
\text { military period, this specifies the military exercise of political influence via a retired or serving } \\
\text { general as president; *** Also known as the 'Rule of Troika', the armed forces influences the politica } \\
\text { decision-making-process under civilian governments from the sidelines; **** supremacy of non- } \\
\text { parliamentary forces (bureaucracy) under formal parliamentary rule; **** The rule of Z.A. Bhuttc } \\
\text { is here called Equilibrium, not Civilian Supremacy despite the fact that civilians had gained extensive } \\
\text { civilian control, but the limits were still set by the military. }\end{array}$} \\
\hline
\end{tabular}

Source: (Wolf \& Kane, 2010, p. 173) 
The people of Pakistan always supported democracy, due to that reason the military rulers were unable to have public support and the system of controlled democracy which they introduced during their rule was also not supported by the peoples. They introduced different electoral projects such as Ayub Khan introduced the Basic Democracies system, through which the member of Provincial Assemblies, National Assemblies and President were to be elected, after that Zia ul Haq and Musharraf (except Yahya Khan) adopted the same strategy to decorate their military rule with the title of democratic name.

Wolf \& Kane (2010, p. 174) in their research stated that "To gain legal and constitutional cover, they focused primarily on two changes in the political-institutional framework. These included first, the transfer of powers from the Prime Minister and Parliament to the President; and second, the introduction of constitutional provisions and institutions which relate to electoral democracy and its constituting elements such as elections, political parties and elected assemblies." On other hand, the democratic government were mostly unable to complete their tenure, except the government of Pakistan People's Party (2008-2013), So, the legislation regarding the accountability and transparency were less concerned.

\section{WHAT IS RIGHT?}

With the passage of time and political awareness the citizens are claiming for more rights to secure and improve their social and political life, because without rights the citizens cannot improve their living standard. As Laski defines that "Right are those conditions of the social life without which no man can seek, in general to be himself at his best" (Haq, 2010, p. 320).

These rights are initially divided into two categories, Moral and Legal rights, the moral rights are recognized by moral sense of individuals while legal rights require state's recognition (Saif-ul-Haq, 2010).

Moreover, the rights are essential for the individual, society as well as for the state. Without rights, individual cannot improve their living standard, they cannot improve their way of life. Rights are also important in society, because without rights the society would be like a jungle in which the system of might is right exists. Moreover, it is the duty of the state to recognize the rights, if the state does not recognize, it loses its patriotism and become a tyranny (Haq, 2010).

Mostly, the rights are made the part of constitution and judiciary is authorized as its custodian. So, the role of the judiciary is significant, due to that reason the judiciary remains independent in most of the political systems.

\section{IMPORTANCE OF RIGHT TO INFORMATION}

Banisar (2011, p. 5) states that "The right of access to information held by government bodies (RTI) provides that individuals have a basic human right to demand information held by government bodies." This right is originated from the freedom of expression which is recognized by all civilized states as a fundamental human right. According to this right any citizen can ask any government body regarding public information and the institutions are bound to respond him, it can be rejected if there is legal reason behind, otherwise the institution must provide information on request. This process ensures the accountable and transparent democratic system. So, the Right to Information is important tool to create checks and balances on the activities of public officials, it creates hindrances in the way of mismanagement, abuse of power and corruption.

Moreover, freedom of expression and freedom of speech are the most important freedoms, which ensure the base of democratic system, without these freedoms the democratic system cannot exists, a system where there is no any freedom of expression and speech that system cannot be said democratic but dictatorship, where no one has such rights. It ensures the right to criticize the policies of the government if they are not in the favour of masses or supporting only a particular community of persons (Singh, 2014).

Access to public related information is the true spirit of good governance, which ensures that what the government is doing for the citizens. If the right to information is given to the common people, in future, they will be more aware and active participant in the government affairs. Which results in more checks and balances on the government, and the governmental policies would be based on openness and transparency because they will feel more accountable (Gunatilleke, 2014). "The strengthening or the establishment of local government is one of the pillars of these reforms in that it constitutes the first step in applying the principles of good governance" (United Cities and Local Governments, 2009, p. 210).

A democratic system creates more accountability, but if it is transparent then it would lead to accountable system. "Good Governance requires that transparency be promoted through devolution of information, having an accountability mechanism for the public functionaries. The process of consultation with the participation of citizens in decision making would gradually become more pronounced in order to ensure 
more accountability" (Jain, 2012, p. 507).

The good governance and right to information are closely linked with each other, so the goals regarding good governance can only be achieved through right to information, if we analyze the essential elements of good governance recognized by world band i.e. participation, accountability and transparency can be achieved through right to information (pandey \& Mishra, 2016).

Since 2000 about 62 countries have recognized access to information as a fundamental right, and 12 countries have amended their previous laws for making more effective this right. During 1990 to 2000 around 23 countries have adopted laws regarding right to information, the idea regarding legislation of freedom of information started in 1766 in Sweden, which is nowadays getting importance around the world. So, mostly 90 developed or developing countries have made legislation to ensure the right to know while majority of other countries have realized its importance and are in the process to legislate to ensure this right. Furthermore, more than 50 countries (including Pakistan) have ensured this right by incorporating it in their constitutions. In different countries, the right to information is expressed in different terms such as "freedom of information, access to information, right to information, right to know, access to public documents and records etc" (Khan, 2013, p. 5).

\section{RIGHT TO INFORMATION AND ISLAMIC REPUBLIC OF PAKISTAN}

The constitution of 1973 Islamic Republic of Pakistan article '19A' clearly states that every citizen shall have the right to have access to information in all matters of public importance subject to regulation and reasonable restriction imposed by law.

Moreover, "On June 13, 2013, the Sub-Committee of Senate on Information and Broadcasting gave final touches to draft Right to Information Act 2013, proposed amendments and asked Ministry of Information and Broadcasting to finalize it by the first week of July for tabling in the Parliament. On August 28, 2013, Senate Committee on Information and Broadcasting approved the draft of Right to Information Act 2013." (Center for Peace and Development Initiatives, 2016, p. 10)

the below mentioned process shows that the implementation of right to information in real sense will create checks and balances process on misuse of power, the corruption could be eradicated and will create a transparent and accountable system, which are the key elements of good governance.

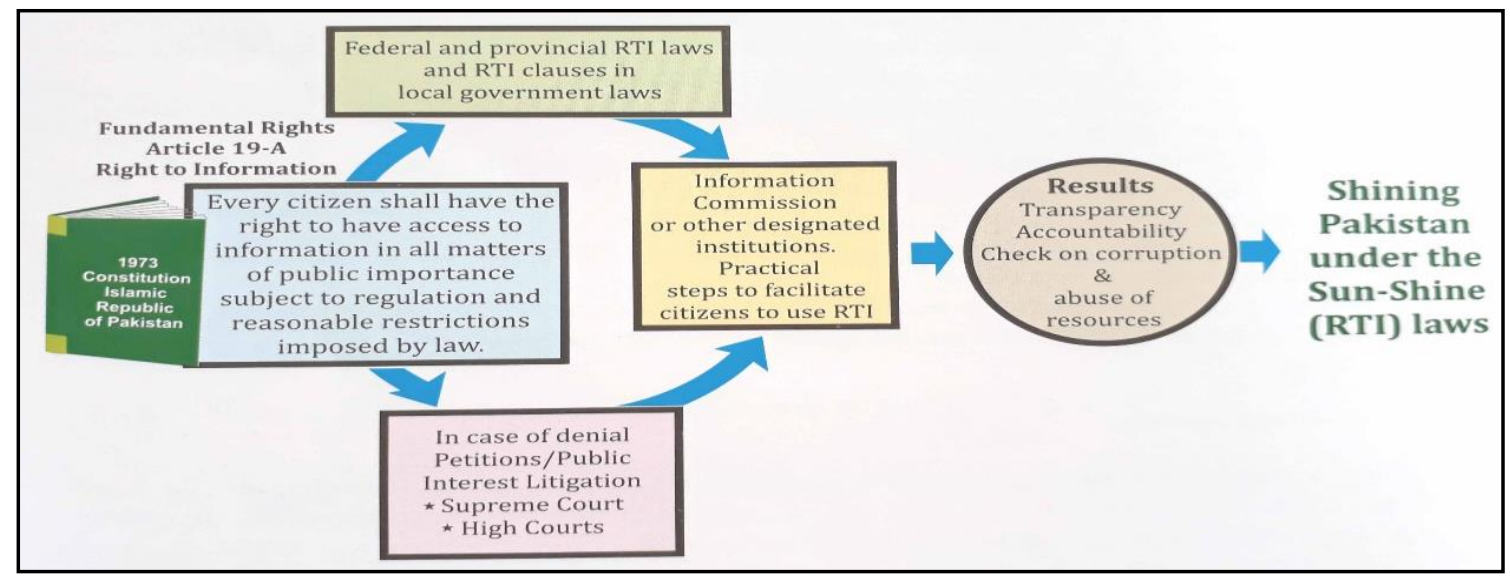

Source: (Khan, 2013, p. 20)

\section{CONCLUSION}

Pakistan was established in 1947 but unfortunately it has been suffering from governance issues, about nine years it has no its own constitution, in 1956 its first constitution was implemented but in 1958 abolished, then second constitution was implemented in 1962 it also did not remain for no long time in practice and abolished in 1969, then third constitution was implemented in 1973 but like previous constitutions it could not remained continue but set in abeyance in 1977. Likewise, the governments in Pakistan could not completed their tenure (except the government of PPP 2008-2013), so previously the right to information was less concerned, another misfortunate is that the laws are made but there is lack of implementation. If the laws are made and implemented in real sense, then the good governance will be the future of Pakistan. The implementation of right to information can play a significant role in democratic country like Pakistan, a country with multi-lingual, multi-cultural and multi-ethnic groups. Furthermore, it will benefit the individuals as well as society as a whole. There could be some hindrances in the way of its implementation but that could 
be removed by taking suitable measures. Moreover, if the complete mechanism of right to information is implemented in real sense in that case it will result in creating transparent and accountable government, hindrances in the way of corruption and create a check on misuse of power. Resultantly there will be good governance in Pakistan in real sense.

\section{REFERENCE LIST}

Banisar, D. (2011). The Right to Information and Privacy: Balancing Rights and Managing Conflicts. Washington DC: The International Bank for Reconstruction and Development/The World Bank.

Center for Peace and Development Initiatives. (2016). Country Briefing Paper: Right to Information Legislation in Pakistan. Islamabad: Center for Peace and Development Initiatives (CPDI).

Chambers, P., \& Croissant, A. (Eds.). (2010). Democracy under Stress: Civil-Military Relations in South and Southeast Asia. Bangkok, Thailand: institute of Security and International Studies, Chulalongkorn University.

Gunatilleke, G. (2014). Right to Information: A Guide for Advocates. Colombo: Sri Lanka Press Institute. Retrieved from http://www.slpi.lk

Haq, M. U. (2010). Political Science: Theory and Practice. Lahore: Bookland.

Hook, S. V. (2011). Democracy. North Mankato: ABDO Publishing Company.

Jain, A. (2012). Good Governance and Right to Information: A Perspective. The Indian Law Institute, 54(4), 506-519. Retrieved from www.ili.ac.in

Kamran, T. (2008). Democracy and Governance in Pakistan. Lahore: South Asia Partnership-Pakistan.

Khan, Z. (2013). Operationalizing Article 19-A Right to Information in Pakistan. Islamabad: Center for Civic Educaiton Pakistan.

pandey, S. K., \& Mishra, A. (2016). Right to Information and Good Governance in India. International Journal of Law and Legal Jurisprudence Studie, 3(2), 362-369.

Saif-ul-Haq, M. M. (2010). Compendium of Political Science. Lahore: Caravan Book House.

Shapiro, I. (2003). The Moral Foundaiton of Politics. New Haven, CT: Yale university Press.

Singh, R. K. (2014, December). Right to Information: The Basic Need of Democracy. Journal of Education \& Social Policy, 1(2), 86-96. Retrieved from www.jespnet.com

United Cities and Local Governments. (2009). Decentralization and local democracy in the world. Barcelona: World Bank and United Cities and Local Governments.

Wolf, S. O., \& Kane, S. (2010). Democratic Ambitions under Praetorlan Stress-Civil Military Relations in Pakistan. In P. Chambers, \& A. Croissant (Eds.), Democracy under Stress: Civil-Military Relations in South and Southeast Asia (pp. 171-200). Bangkok, Thailand: Institute of Security and International Studies, Chulalongkorn University. 